\title{
Corporate Social Responsibility and Stakeholder Theory: Learning From Each Other*
}

\author{
R. Edward Freeman ${ }^{* *}$, Sergiy Dmytriyev ${ }^{* * *}$
}

\begin{abstract}
This paper explores the relationship between two major concepts in business ethics stakeholder theory and corporate social responsibility (CSR). We argue that CSR is a part of corporate responsibilities (company responsibilities to all stakeholders), and show that there is a need for both concepts in business ethics, and their applicability is dependent on a particular problem we want to solve. After reviewing some criticisms of CSR - covering wrongdoing and creating false dichotomies, we suggest that incorporating some findings from recent research on stakeholder theory can help align both concepts and overcome the criticisms. At the end of the article, we outline potential directions for future research on CSR.
\end{abstract}

Keywords: Corporate Social Responsibility (CSR); Stakeholder Theory; Corporate Responsibilities; Global Business

\section{Introduction}

There is a new story of business that is emerging throughout the world. Part of that new story is the increased importance of ideas such as corporate social responsibility (CSR). While the full story of this new narrative is for another occasion (Freeman, Parmar, \& Martin, forthcoming), we want to take this opportunity to suggest that CSR or corporate responsibility (CR) can play an important role as our theory of business evolves towards one worthy of $21^{\text {st }}$ Century ideals for human beings.

Throughout the history of the idea of corporate social responsibility, there has been controversy. In the latter part of the last century, this controversy erupted into a full-scale ideological battle. The so-called "champions of free markets", led by Professor Milton Friedman of the University of Chicago, argued that CSR was essentially an immoral idea, violating the rights of the "owners" of businesses (Friedman, 1970). By using

\footnotetext{
* Invited Article

*** Elis and Signe Olsson Professor of Business Administration, Darden School of Business, University of Virginia (FreemanE@darden.virginia.edu)

*** Researcher in Business Ethics, Darden School of Business, University of Virginia (dmytriyevs16@darden.virginia.edu)
}

Freeman, R.E. \& Dmytriyev, S. (2017). Corporate Social Responsibility and Stakeholder Theory: Learning From Each Other, Symphonya. Emerging Issues in Management (symphonya.unimib.it), 2, 715. 
corporate resources to solve non-business "social" problems, the executives engaging in CSR were stealing from shareholders. They argued that if shareholders wanted to use their resources in such a way they could do so themselves privately. The so-called "Chicago School" developed into a full-blown ideology that profoundly changed the business landscape and exists even today in most major business schools and financial centers around the world.

The critics of this ideology are legion. There have been countless takedowns of the assumptions built into the Chicago School ideology, and hardly a month goes by without another article showing how "homo economicus" doesn't tell us much about the real world. The CSR literature developed in management and business ethics often as a counterpoint to this ideology. In reality, the debate is one more instantiation of the BerleDodd debate much earlier in the $20^{\text {th }}$ Century about the purpose of the corporation (Berle, 1931; Dodd, 1932).

However, the idea of CSR has itself become contested. It has been criticized from a number of differing and conflicting points of view, each assuming a quite different version of both CSR and "business". As we have been one of these critics of the idea of CSR (Freeman, 1984), but have never accepted the Chicago School ideology, we want to use this brief essay to propose some more helpful ideas about when the idea of CSR can be useful, its relationship to stakeholder theory, and how we can "dissolve", in a Wittgensteinian sense, the tension between "free markets" and "corporate social responsibility".

In what follows, we take the following route. In section II, we recap the criticisms of CSR to show the contestability of the basic concept. In section III, we analyze where CSR and stakeholder theory stand in relation to each other. In section IV, we suggest a set of criteria that can help align CSR and stakeholder theory and overcome the criticism. In section $\mathrm{V}$, we provide research questions that have the potential to contribute to the future landscape of CSR research.

\section{The Contestability of CSR}

The critique of CSR can be grouped into three main arguments:

1. Violating obligation to shareholders. It is Friedman's argument described above that presupposes that business works based on the principles promoted by traditional economics theory.

2. Covering wrongdoing. CSR is criticized for creating a distorted view of business. It became commonplace to consider business as a necessary evil for society and to perceive executives as short term economic maximizers of their own self interest. To recover their reputation, business executives need to do something good namely, CSR. According to this view of business, managers are akin to gangsters going to church on Sundays. Another type of covering wrongdoing, but in a different sequence, refers to CSR's moral licensing, when doing good things for communities can create a misleading feeling of being excused for mistreating some other stakeholders (Ormiston \& Wong, 2013). One more type of covering wrongdoing could be found in "window-dressing" used to pre-empt government from enforcing 
stricter regulations on certain products, business activities, or industries. All these perceptions of CSR as a tool for covering wrongdoing can to a certain extent be considered a result of false dichotomies discussed in the next argument.

3. Creating false dichotomies. CSR could be criticized for furthering a set of questionable distinctions such as Economic vs. Social, Business vs. Ethics, Profits vs. Society. These unnecessary distinctions became adopted as social science orientation of business schools finding their way into the curriculum taught in MBA classrooms as well as in academic research.

The first criticism of CSR, violating obligation to shareholders, has been disproved by both scholars and lawyers alike (Stout, 2012; Freeman, Harrison, Wicks, Parmar, \& de Colle, 2010), thus there is no need for us to elaborate on it further here. However, the other two arguments impose a substantial challenge to CSR. Helping communities should not be treated as a redemption tool for excessive greediness in business, and CSR should not be used to cover wrongdoing toward other company stakeholders. When it comes to creating false dichotomies, we believe that economic cannot be separated from social, business and ethics cannot be isolated one from the other (Freeman, 1994; Harris \& Freeman, 2008), and making profits and serving society are not moving in opposite directions.

Here, we believe, some ideas of stakeholder theory can be helpful for CSR, and vice versa. But before we proceed with these ideas, it is necessary to clarify how CSR and stakeholder theory relate to each other.

\section{The Relation between CSR and Stakeholder Theory}

Whenever one talks about business ethics - either in terms of scholarship, or the discipline taught in business schools, or organizational norms applied in companies both CSR and stakeholder theory come as two major concepts. However, there has been little clarity so far in what relation CSR and stakeholder theory stand to each other.

Some scholars assumed that one concept is a subset of the other (Garriga \& Mele, 2004; Wood, 1991), others saw these concepts as somewhat competing views in the field (Brown \& Forster, 2013; Schwartz \& Carroll, 2008), and others built their arguments on the complementarity of CSR and stakeholder theory (Russo \& Perrini, 2010; Jamali, 2008; Kurucz, Colbert, \& Wheeler, 2008; Roberts, 1992). Yet, the majority of scholars in business ethics and beyond did not preoccupy themselves with this question and were writing either within one or the other stream of research without carefully examining the relationship between the two.

However, given that the body of research on CSR and stakeholder theory has considerably grown over the last decades and both concepts often look at the same business issues from different points of view, we believe that some clarity in this regard might be helpful to resolve unnecessary tension or confusion between the two streams of thought.

We see stakeholder theory and CSR as distinct concepts with some overlap. The main similarity between the two concepts is that both stakeholder theory and CSR stress the importance of incorporating societal interests into business operations. Businesses are 
embedded in society always. They are never as separate as the defenders of neoclassical theory try and pretend. At the same time, the two concepts differ in that stakeholder theory posits the key responsibilities of the business overall, i.e. corporate responsibilities, where responsibility to the society (which is often represented by the communities where business operates) is a very important but only one part among other corporate responsibilities. CSR prioritizes one aspect of business - its orientation toward the society at large, i.e. its social orientation - over the other business responsibilities.

Stakeholder theory posits that the essence of business primarily lies in building relationships and creating value for all its stakeholders. Though the composition of stakeholders may differ depending on company's industry and business model, the main stakeholders typically include employees, customers, communities, suppliers, and financiers (owners, investors). All these stakeholders are equally important for the company and any trade-off among the stakeholders should be avoided. Rather executives need to find ways that these interests can be guided into the same direction.

When it comes to CSR, it is an umbrella concept for company's activities oriented toward society at large that includes charity, volunteering, environmental efforts, and ethical labor practices. Differently from stakeholder theory, CSR neither attempts to understand what business in its entirety is about nor tries to stipulate its overall range of responsibilities. Instead, CSR focuses on one stream of business responsibilities responsibility to local communities and society at large - to ensure business does deliver on it. Although sometimes social responsibilities could be organized per stakeholder, social orientation would still prevail there.

Figure 1 provides a visual illustration of the relationship between stakeholder theory and CSR. Both stakeholder theory and CSR stress the importance of company responsibility toward communities and society. However, stakeholder theory tends to center its attention within a reasonable reach of company's activities, thus focusing on local communities where the company operates (see Figure 1's inner circle that stands for primary stakeholders) and surrounding society, a bigger area where local communities reside, e.g. city or district (Figure 1's outer circle that stands for secondary stakeholders). While CSR tends to extend the social orientation of the company much further, often to its maximum. For instance, it is not uncommon to hear from the CSR adherents that companies need to help fight diseases and alleviate poverty in remote parts of the globe, even if the company has no single operation there and no particular expertise in doing either task.

When it comes to company responsibilities toward employees and customers, CSR mainly focuses on ethical labor practices and environmental efforts, while stakeholder theory tries to embrace company responsibilities toward these stakeholders in full, as well as the stakeholders' responsibilities towards the company and its other stakeholders (so responsibility is multi-directional). Stakeholder theory also addresses company responsibilities toward financiers and suppliers; while CSR does not emphasize these particular stakeholder groups (even though recently there has been some work on sustainable supply chains with suppliers) and sees responsibility as uni-directional (from the company to communities and society). 
Figure 1: The relation between Stakeholder Theory and CSR

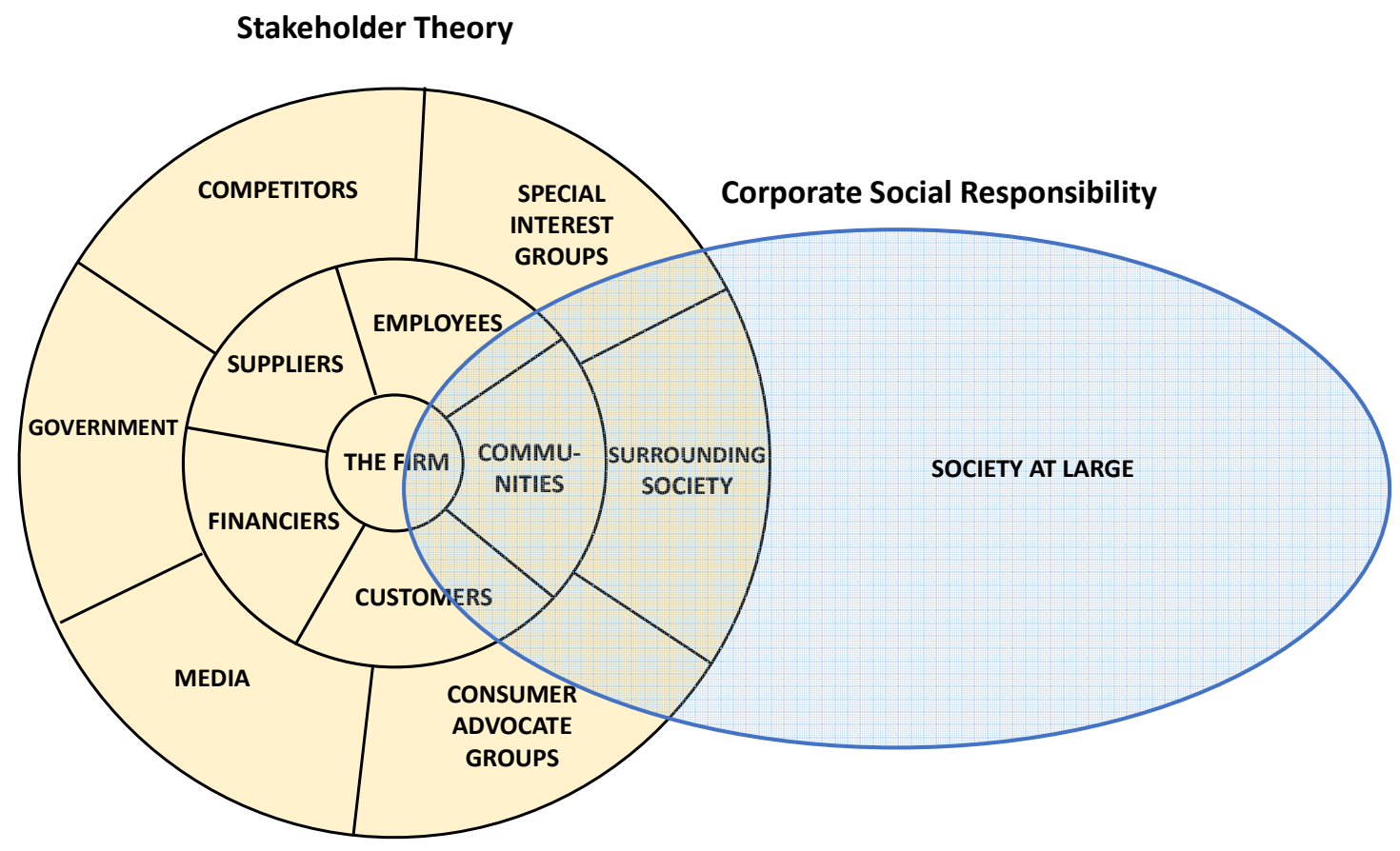

Another way to explain differences between stakeholder theory and CSR is to recognize the difference in perspectives from which each of these concepts looks at the company. Stakeholder theory mainly looks at the company from the perspective of the company itself, and from the perspective of company's immediate stakeholders. This perspective is formed by stakeholder theory's claim that the company has responsibility to operate in the interests of all its stakeholders (Freeman, 1984). Furthermore, stakeholder theory posits that stakeholders are interdependent, and creating value for one stakeholder creates value for the others (Freeman et al., 2010). CSR looks at the company from another perspective - society at large. Subsequently, CSR prioritizes certain company responsibilities over the others, namely company responsibilities to society (mainly communities and partially employees and customers, in stakeholder terms) over the responsibilities to other stakeholders (e.g. to financiers, suppliers, and omitted responsibilities to employees and customers).

Although CSR and stakeholder theory often look at the same issues in management, from different perspectives, we believe that the languages of both concepts can be useful, and their application is dependent on the particular problem we want to solve. If we look at the company holistically, taking into account its overall purpose, mission, values, effectiveness, productivity, and its impact on all company stakeholders, then stakeholder theory can be a useful tool to provide guidance on how the company should operate overall. Stakeholder theory stipulates company's responsibilities to all their stakeholders - such as responsibility to customers, responsibility to employees, responsibility to financiers, responsibility to suppliers, and responsibility to communities. Altogether, all 
these company's responsibilities to stakeholders could be denoted under the term corporate responsibilities.

At the same time, it does sometimes make sense to separate out some key stakeholder relationships i) for special expertise, similarly to how marketing does it with customers, or finance with financiers, or ii) for those areas where a company is doing an especially poor job. This is where the language of CSR can often be a useful tool to single out responsibility to communities, or society at large, as worthy of special attention. To demonstrate the point, we may refer to the civil rights movement "Black Lives Matter" in the US. Of course, all lives matter. But given a long history of oppressing African Americans in the country, it makes sense to prioritize one part of the society so that everyone's attention is drawn to the current problem until civil rights violations toward the oppressed group have been resolved.

In other words, when we talk about how a company should operate in general, we can use the term corporate responsibilities referring to company's responsibilities to all its stakeholders, who are all equally important. At the same time, there will also be occasions when it makes sense to narrow down our focus to company's responsibility to a particular stakeholder, and denote it correspondingly. For instance, when we want to stress company's responsibility to local communities or society at large, we may add social to emphasize the need for social orientation of the company, thus arriving to the term corporate social responsibility.

Indeed, corporate social responsibility (or CSR) mainly deals with social issues. For instance, the scope of CSR would typically be improving access to education among community members (or society at large), providing them with better health care opportunities, or improving their environmental conditions. However, CSR does not go beyond social responsibility of the company. For example, CSR is not the term that comes first to mind when the company has to deal with the issues of creating meaningful work or long-term career opportunities for company employees, providing sustainable contract terms or building reliable partnerships with company suppliers, addressing consumer needs or providing the best value for money for customers, informing investors about the key strategic decisions or utilizing shareholders' assets in the most productive way. These issues are part of corporate responsibilities that go beyond the CSR domain.

\section{Aligning CSR and Stakeholder Theory}

Corporate social responsibility is not only part of corporate responsibilities; these two concepts are deeply interconnected. There are common elements - Purpose, Value Creation, and Stakeholder Interdependence - that make corporate responsibilities overall, and corporate social responsibilities in particular, unified.

Purpose. In the very first place, company's existence starts from its purpose. There is usually some need in the world that inspires the birth of an organization and as the company matures, its purpose should never be forgotten. Thus, each company should be purpose-driven, meaning that the purpose should equally i) determine the direction in which the company is heading - corporate vision, mission, and strategy, and 2) stipulate 
corporate responsibilities along the way. It is also important to remember that from the very beginning the purpose should lie within the ethical domain. Such morally situated purpose defends an organization against the rise of false dichotomies of economic vs social, business vs. ethics, or stakeholder interests vs. societal interests.

Value Creation for All. Stakeholder theory posits that companies need to create value for all stakeholders. This is how Purpose - inspiration that led to the birth of the company - gets materialized in practice. Realizing that business is about creating value for customers, employees, financiers, suppliers, and communities counteracts a temptation to use CSR for covering wrongdoing with some other stakeholders as the reason for wrongdoing some other stakeholders is weakened. Doing good in the area of CSR is as important as creating value for other stakeholders. This resonates with Freeman et al.'s (2010) description of residual and integrated approaches to CSR, where the latter is giving back to society only after profits are made, while the former is about integrating economic with social, environmental, and ethical decision-making criteria.

Stakeholder Interdependence. It is a common belief that business is about making decisions, and in the world of limited resources, business decisions involve trade-offs. If companies help communities, then shareholders will receive a lower return on their investment. Or, if the company provides very good terms for their suppliers, then customers will have to pay for products more. Or, if the company offers way-above-themarket-average compensation package to its employees, then the rest of stakeholders will receive less value. Apparently, these are false dichotomies. What is omitted in this logic is that stakeholders are interdependent and creating value for one stakeholder also contributes to creating value for others. Helping communities can make shareholders better off in many ways (more motivated and productive employees, better company reputation, bigger sales, higher corporate credit rankings); likewise, satisfiying suppliers or employees is also beneficial for customers.

\section{Some Research Suggestions for Corporate Responsibility (CR)}

Here we would like to offer a few suggestions on potential future research that would help CSR overcome its criticism:

(1) What is the connection between particular corporate responsibilities (such as CSR) programs and the purpose of particular companies? We should get away from the tired old 'does CSR pay off?' There is nothing wrong in exploring the question of whether CSR activities contribute to company's positive bottom line. What is wrong is to start with this question. The initial question should be whether corporate responsibilities, or CSR in particular, are aligned with company's purpose and its connection to ethics and values; and if the answer is 'yes', then we can examine whether it pays off. Though, in our view, it is much more interesting and more relevant to explore how CSR creates value for all stakeholders, rather than looking at CSR's contribution only to shareholders. (2) What is the variety of CSR programs that build communities? Following from here, we may wonder, is there a difference among companies who are explicit community builders and those who are not? And, does this make a difference to other stakeholders? 
(3) What is the connection between this stakeholder oriented idea of corporate responsibilities and other "fixes" to capitalism like Conscious Capitalism, Shared Value, Stakeholder Oriented Strategic Management, Capitalism 2.0, etc.

(4) Finally, under what conditions is the language of corporate responsibilities preferred to the language of corporate social responsibilities, and vice versa? How does framing as corporate responsibilities or corporate social responsibilities work?

\section{Conclusion}

In this paper, we attempted to analyze how CSR and stakeholder theory relate to each other. We argued that corporate social responsibility is a part of corporate responsibilities oriented toward all stakeholders, and showed that the languages of both CSR and stakeholder theory are useful depending on a particular problem we would like to solve. We also argued that some contestability of CSR - covering wrongdoing and creating false dichotomies - could be overcome by adopting the latest findings in stakeholder theory. In particular, companies should be purpose-driven (purpose should reside within moral domain), they need to create value for all stakeholders, and stakeholders are interdependent. As such, creating value for communities (CSR), does not create tension in value creation for other stakeholders.

\section{Bibliography}

Berle, A.A. (1931). Corporate powers as powers in trust. Harvard Law Review, 44(7), 1049-1074. https://doi.org//10.2307/1331341

Brown, J.A. \& Forster, W.R. (2013). CSR and Stakeholder Theory: A Tale of Adam Smith. Journal of Business Ethics, 112, 301-312. https://doi.org//10.1007/s10551-012-1251-4

Carroll, A.B., Post, J.E., Lipartito, K., \& Werhane, P.H. (2012). Corporate Responsibility: The American Experience. Cambridge University Press.

Dodd, E.M. (1932). For whom are corporate managers trustees? Harvard Law Review, 45(7), 1145-1163.

Freeman, R.E. (1984). Strategic Management: A Stakeholder Approach. Pitman Publishing.

Freeman, R. E. (1994). The Politics of Stakeholder Theory: Some Future Directions. In Stakeholders by Robert A. Phillips and R. Edward Freeman (eds.). Northampton, MA: Edward Elgar Publishing Ltd.

Freeman, R.E., Harrison, J.S., Wicks, A.C., Parmar, B.L., \& De Colle, S. (2010). Stakeholder theory. The state of the art. New York: Cambridge University Press.

Freeman, R.E., Parmar, B.L., \& Martin, K.E. Business: The New Story. Columbia University Press. Forthcoming.

Friedman, M. (1970). The Social Responsibility of Business is to Increase its Profits. The New York Times Magazine. September 13.

Garriga, E., \& Mele D. (2004). Corporate Social Responsibility Theories: Mapping the Territory. Journal of Business Ethics, 53, 51-71.

https://doi.org/10.1023/B:BUSI.0000039399.90587.34 
Harris, Jared D., \& R. Edward Freeman. (2008). The impossibility of the separation thesis: A response to Joakim Sandberg. Business Ethics Quarterly, 18 (4), 541-548.

https://doi.org/10.5840/beq200818437

Jamali, D. (2008). A Stakeholder Approach to Corporate Social Responsibility: A Fresh Perspective into Theory and Practice. Journal of Business Ethics, 82, 213-231.

https://doi.org/10.1007/s10551-007-9572-4

Kurucz, E. C., Colbert, B. A., \& Wheeler, D. (2008). The business case for corporate social responsibility. In A. Crane, A. McWilliams, D. Matten, J. Moon, \& D. Siegel (Eds.), The Oxford handbook of corporate social responsibility, 83-112. Oxford: Oxford University Press. https://doi.org/10.1093/oxfordhb/9780199211593.003.0004

Ormiston, M.E., \& Wong E.M. (2013). License to ill: The Effects of Corporate Social Responsibility and CEO Moral Identity on Corporate Social Irresponsibility. Personal Psychology, 66(4), 861-893. http://dx.doi.org/10.1111/peps.12029

Robert, R.W. (1992). Determinants of corporate social responsibility disclosure: An application of stakeholder theory. Accounting, Organizations, and Society, 17(6), 595-612.

Russo, A., \& Perrini, F. (2010). Investigating Stakeholder Theory and Social Capital: CSR in Large Firms and SMEs. Journal of Business Ethics, 91, 207-221.

https://doi.org/10.1007/s10551-009-0079-z

Stout, L. (2012). The Shareholder Value Myth: How Putting Shareholders First Harms Investors, Corporations, and the Public. San Francisco, CA: Berrett-Koehler Publishers.

Schwartz, M.S., \& Carroll, A.B. (2008). Integrating and Unifying Competing and Complementary Frameworks: The Search for a Common Core in the Business and Society Field. Business \& Society, 47(2), 148-186.

https://doi.org/10.1177/0007650306297942

Ullmann, A. (1985). Data in Search of a Theory a Critical Examination of the Relationship Among Social Performance, Social Disclosure, and Economic Performance. Academy of Management Review, 540577.

Wood, D.J. (1991). Corporate social performance revisited. Academy of Management Review, 16(4), 691718. 